\title{
SPATIAL CHARACTERISTICS OF ART TRADE IN HUNGARY
}

\section{A MÜKERESKEDELEM TÉRBELI SAJÁTOSSÁGAI MAGYARORSZÁGON}

\author{
Ibolya VÁRNAI ${ }^{\mathrm{a}}$ \\ ${ }^{a}$ PhD student at Szent István University, Enyedi György Doctoral School of Regional Sciences, H-2100 \\ Gödöllő, Páter Károly utca 1. E-mail: varnai.ibolya@gmail.com
}

Cite this article: Várnai, I. (2018). Spatial Characteristics of Art Trade in Hungary. Deturope, 10(1), 131-143.

\begin{abstract}
Century-long traditons of art trade in Hungary are strongly connected to the capital, famous, elite auction houses and galleries are concentrated in the downtown area of Budapest. Although art market in Hungary is capital-centered, remarkable amount of art trade takes place in the countryside too. This study aims to give insight into the presence of the different types of art trade (antique shops, second-hand book stores, art galleries and auction houses) in rural settlements, compared to the characteristics of art trade in Budapest. The research - based on primary data collection - reveals the social, economic, and cultural factors which explain the regional differences in art trade.

During the field work in Budapest, semi-structured interviews were conducted with art gallery owners, auctioners, and antiquarians. The penetration index (PEX) which was applied in the case of researches in the countryside shows the rate in which the different types of art trade are present in settlements of different sizes. The results are demonstrated on the map with the help of the Mapinfo 12.5 software.
\end{abstract}

Keywords: art trade, auction house, art gallery, antique shop, second-hand bookstore

\begin{abstract}
Absztrakt
Magyarországon a műkereskedelem évszázados hagyományai erőteljesen kötődnek a fővároshoz, a nagy múltú, előkelő aukciósázak és galériák jellemzően Budapest belvárosában koncentrálódnak. Bár a mütárgypiac hazánkban erősen főváros-centrikus, számottevő mükereskedés található országszerte vidéken. Jelen tanulmány a mükereskedések típusainak (régiségboltok, antikváriumok, galériák és aukciósházak) vidéki településeken való jelenlétét hivatott bemutatni, összevetve a budapesti műkereskedelem sajátosságaival. A primer adatokra épülő kutatás azt kívánja feltárni, hogy milyen társadalmi, gazdasági, kulturális tényezőkkel magyarázhatóak a mükereskedelem regionális különbségei. A budapesti terepmunka során félig strukturált interjúk készültek galériatulajdonosokkal, becsüsökkel és antikváriusokkal. A vidéki vizsgálatok esetében alkalmazott penetrációs index (PEX) számítás azt mutatja meg, hogy a különböző települési méretkategóriákban a műkereskedések adott típusai milyen arányban jelennek meg. Az eredmények térképi megjelenítése Mapinfo 12.5 térinformatikai szoftver segítségével valósult meg.
\end{abstract}

Kulcsszavak: műkereskedelem, aukciósház, kereskedelmi galéria, régiségbolt, antikvárium

\section{INTRODUCTION}

When it comes to Hungarian art trade, several types of art markets exist at the same time (Rechnitzer, 2002), according to which type of art the individual sub-markets specialize in 
(e.g. paintings, furniture, retro artifacts, etc.). In these sub-markets the economic, cultural heritage protection, art and private sectors are present parallel to each other. In our research profit-oriented art trade businesses will be examined. Based on their profile, these art trade businesses can be classified as antiques shops, art galleries, auction houses, gallery auction houses, and second-hand bookshops also belong here (Várnai, 2017). Taking this as a starting point, art trade can be regarded as an industry of cultural economy, which formulates the competitiveness of cities (Enyedi, 2012), or as a special segment of retail trade where valuerestoring antique (Sikos, \& Hoffmann-né, 2004) and contemporary artifacts are bought and sold. Art market belongs to the traditional segment of creative industry (Hartley-Ormerod 2008, Pratt-Jeffcutt 2009, Dekker, 2015). Although it accounts only for a small part of the whole economy (Prinz-Piening-Ehrmann, 2015), it is highly important from a cultural point of view. As business policy, price strategy and target customers of the different types of art traders differ, their site selection and spatial diffusion can also be rather different. This study aims to introduce the spatial characteristics of Hungarian art trade, and to examine what factors influence the spatial concentration and separation of the different types. The topic raises current and interesting issues in the case of Hungary, because it is rather capitalcentered: social, econimc, political and cultural life is concentrated in Budapest. The locationspecific, metropolitan feature of the industries of cultural economy (Enyedi, 2002) can also be observed in the case of Hungarian art trade; the largest, most elite trading houses and galleries are almos all concentrated in Budapest. The traditional center of art trade in Budapest is Falk Miksa utca in the downtown area, while Múzeum körút preserves the traditions of trading in second-hand books. At the same time, art trading, which is conducted in antiques shops and galleries, receive little attention. So the question is obviuos: how can spatiality of art trade in the countryside be characterised? What similarities and differences can be observed when we compare the spatial distribution of the different types of art traders?

Accordingly, this paper introduces the presence of art shops in Budapest and in the countryside, highlighting the major spatial features and characetristics. The author examines on which level of the settlement hierarchy the different types appear, and what social, economic and cultural factors explain the regional differences in art trading. 


\section{APPLIED METHODS}

The database, which served as a basis for the examination, was built on a primary research, when with the help of search engines the exact address and main profile of art shops were collected. The author assumes that for operating a healthy and effective business nowadays it is essential to be present in electronic business registers.

The study relies partly on the previous researches of the author, which are completed by new researches. The latest data collection took place between March and June 2017, when the database was extended with another 95 new entries, comprising now of 377 art shops in the capital. During the research period data - borken down by profile - about a total of 290 art shops operating in the country were collected (Tab. 1). To be able to understand the site selection policy of the shops and to discover the regional characteristics of art trade, the data base contains available information on price policy, supply channel and selection of goods. The study does not deal with the characterististics of online art trade, or with the spatial charcateristics of auctions in virtual space; it researches only the factors which influence the locality of art shops and their being bound to geographical space (Nemes Nagy 2009, p. 88.). It is also worth distinguishing those trading houses which provide opportunity only for online shopping and bidding. Some of them mainly play an intermediary role between sellers and buyers (C2C marketplaces) or serve as an advertising platform for users, while others operate as webshops or online auction houses without maintaining a physical shop. In some art shops potential buyers are able to see the items prior to the online auction/sale, the spatial presence of these shops carry the characteristics of traditional antiques shops and galleries. When collecting the database, the author considered the latter type.

Table 1 Distribution of art shops by profile in Hungary, 2017 (pcs)

\begin{tabular}{c|cccc}
\hline \multirow{2}{*}{ Area } & \multicolumn{4}{|c}{ Profile of art trade shops } \\
\cline { 2 - 5 } & $\begin{array}{c}\text { second-hand } \\
\text { bookshop }\end{array}$ & $\begin{array}{c}\text { antiques } \\
\text { shop }\end{array}$ & galleries & $\begin{array}{c}\text { auction houses and } \\
\text { gallery auction } \\
\text { houses }\end{array}$ \\
\hline Budapest & 96 & 140 & 104 & 37 \\
\hline countryside & 98 & 110 & 78 & 4 \\
\hline
\end{tabular}

To the further analysis of the evolvement of traditional art trade centers, the author also relied on another qualitative research methods. Semi-structured interviews were conducted with the owners and employees of art galleries, antiques shops and second-hand bookshops in Budapest. The experiences of these interviews contributed to the understanding of the socio- 
economic traditions and the history of the city's development in the typical core areas. The aim of these field works was to understand the main features and characteristics of art shops of different profiles better, as well as to further specify primary data.

To analyze the spatial distribution of art shops in the countryside, applying the penetration index (PEX) proved to be useful (Tiner 2010). This index shows that in how many percantages of the settlements of a given size is the given type of art shop present at least with one shop. The author classified the settlements into five catergories on the basis of the number of permanent inhabitants (National Regional Development and Spatial Planning Information System (SIS) data from 2016), then the data were summarized on a spreadsheet, in each individual group indicating the number of settlements where the different types of art shops are present. When examining spatiality, spatial information technology methods were used. By using Mapinfo 12.5 software, art shops in the database were represented on the map after the exact address of the shops had been geocoded. To examine spatial similarities and differences each and every type was given a different symbol. Spatiality of art shops in the capital and in the countryside are represented on different maps in the study, in case of Budapest the map indicates the district, while the other map shows the county borders.

\section{RESEARCH RESULTS}

\section{Regional differences in art trade in Hungary}

As the data in Table 1 show, a total number of 377 art shops operated in Budapest in the examined period, while the number of art shops registered in the other parts of the country was the three-quarter of it (290). Although the most significant events in art trading are connected to Budapest, the numbers show the significance of art trade in the countryside. If we exmine the distribution of art shops according to their profile, the most remarkable difference can be depicted in the number of auction houses. While the number of gallery auction houses operating in the countrside is only four, this number in Budapest is more than nine times bigger. Considerably more galleries and antiques shops can be found in the capital than in the countryside, but the degree of their superiority in the number is less, only $27-33 \%$. Only in the case of antiques shops can we observe a larger number of stores in the countryside, their number is almost identical in Budapest and in others settlements (96-98). The most influential players of the Hungarian art market are the different auction houses, but at the same time this type is the least widespread. Among them we can distinguish gallery auction houses and auction houses (without a gallery function). Considering their numbers, 
these make up $10 \%$ of the art shops in Budapest, while they account only for $1.4 \%$ in the countryside. All these prove the metropolitan characteristics of art trade, trading houses with a long history are primarily located in the capital. Auction houses and gallery auction houses apply a mixed price strategy (combining fixed and bidding price policies), sales can take place in the traditonal and in the virtual space too. Trading houses, except for the Villás Galéria és Aukciósház in Debrecen, display their selection online too. The Párisi Galéria és Aukciósház from Pécs holds its auctions in its Budapest site, and the goods of two other auction houses can only be bid for on one of the virtual art markets. Commercial art gallareies account for one-quarter $(27 \%)$ of the Hungarian art traders. They mainly use traditional distribution channels, and do not hold auctions. Galleries are important players in contemporary art life; they play a significant role in the market success of young artists (Meyer-Even 1998), apart from promoting the recognition of the artists and their development, they often provide home for exhibitions, art events. The distribution of the number of galleries is similar in both areas $(27 \%)$, but their larger concentration in the capital can also be observed. The most widespread type of art shops is antiques shops. These shops account for more than one-third of the Hungarian art traders.

As for the layout and inner design of the antiques shops, gallery-like design, stores with smaller or larger shop floors are suitable for displaying the rich selection of art pieces. Athough in many cases the provided sets of information on the different antiques shops were not complete, it is interesting that while only $10 \%$ of the shops in the capital offer online shopping possibility, in the countryside this rate is over $17 \%$. Considering the fact that art pieces are usually passion goods of great value, for the antiques shops operating in the country it is essential to improve competitiveness, which can explain their presence on the online market. While antiques shops in Budapest have their own websites, shops operating in the countryside, probably considering the reasons of economies of scale, use $\mathrm{C} 2 \mathrm{C}$ online marketplaces. Bidding price policy is less characteristic of antiques shops, only less than $10 \%$ of them apply it.

In Budapest one quarter of art shops are second-hand bookshops, in the countryside this rate is higher, around $34 \%$. There is a considerable difference regarding online trade. In Budapest $36.5 \%$ of second-hand bookshops use multi-channel distribution, in the country only $30.6 \%$. We should note that $22-25.5 \%$ of the second-hand bookshops both in Budapest and in the countryside created their own website. The wider range of these stores located in Budapest use services of online marketplaces and advertising portals. For online shops and auction houses quick availability and delivery of the ordered/auctioned goods is of key importance. Regarding the fact that these online markets mostly have their headquarters in Budapest, 
second-hand bookstores operating in the capital have a considerable advantage in distribution against their competitors from the countryside; and this can explain regional differences in distribution channels. Similar to antiques shops, second-hand bookshops can be less characterized by combined price policy, most of them work with fixed prices.

\section{Spatial characterisics of art trade in the capital}

The distribution of the different types of art traders can be differentiated not only in the capital-countryside relation, but a rather unique pattern can be observed inside Budapest too. Second-hand bookshops are mostly located in the inner districts of Budapest, in the area embraced by the boulevards. In the downtown area (district V) can be found $25 \%$ of the second-hand bookshops, while another $30 \%$ are located in the neighboring districts (VI, VII and XIII). Shops concentrated in the southern part of district V form the traditional center of second-hand book trade in Budapest (Fig. 1). Traditions of trading in second-hand books in Múzeum körút probably go back to the second part of the $19^{\text {th }}$ century. As it turns out from the research interviews, the very first second-hand bookshop in the boulevard appeared in 1891, and played a leading role in trading books in the capital. In selecting the site, the nearby universities and other educational institutions must have played a key role. Second-hand bookshops specialized in medical and music books were shortly followed by other bookstores on the boulevard, and with time the special array of second-hand bookshops evolved. Although private stores were closed down during the socialist era, only state-owned bookshops were allowed to trade in second-hand books, after the change of the regime, retailing in used books had a new impetus. Another second-hand bookshops operate in Buda in district I, II and XI, where about $18 \%$ of the shops are located.

Antiques shops - matching the spatial pattern of second-hand bookshops - are located along the boulevards and the neighboring side-streets. $29.3 \%$ of the shops are centered in district $\mathrm{V}$, and their number is also significant in the districts next to the city center $(32.2 \%)$. In district II there are 11 antiques shops, and in district I, XI and XII another 6-7 shops can be found. While the traditional center of trading in second-hand books is inevitably the Múzeum körút, in case of antiques shops a similar core-area cannot be pointed out. Although antiques shops and second-hand bookshops are represented in the downtown in a larger number, both types are rare in the core of the city, in the so-called traditional shopping zones (Sikos T. Hoffmann-né 2004). This phenomenon can be explained by the observation of Sikos T. (2000), according to which the secondary shopping zone which embraces the downtown area (the southern part of district V, Rákóczi út, Nagykörút) can be characterized by mainly shops of smaller shopping floor size, which are forced out of the center because of the high rental 
rates. In the downtown retail units, which became empty after the appearance of big shopping centers, not only reputable specialized stores, but respectable second-hand bookshops and antiques shops could find their homes.

Spatiality of commercial art galleries can be characterized by pronounced spatial concentration. The quarter of galleries can mainly be found in district V in Falk Miksa utca and its sidestreets, but it is extended to the whole Central Business District (CBD) area. 54\% of commercial galleries are centered here, a smaller part of them are located in the close neighborhood of district V. District VI provides home to 13 galleries, and another 7-7 galleries operate in districts VIII and IX. In the Castle District in Buda and in districts II and XI 5-6 galleries work on the average, making up $16 \%$ of the total number of galleries in Budapest. $65 \%$ of trading houses - a sub-type of auction houses - are located in the most elegant areas in the city center. Among them we should distinguish the dispersion of gallery auction houses and auction houses. Out of the 24 trading houses in the CBD 19 are prestigious and elegant ones, because they are the ones able to finance the high rental fees. Compared to this, only $42 \%$ of the auction houses settled down in the business district. For them - probably because of the common, online distribution channel strategy - central location is not always essential, another aspects can also play an important role in site selection.

As the author sees it, spatial development of the traditional art trade center can be led back to two major factors. Firstly the building of the modern city center in the first part of the $20^{\text {th }}$ century and the development of the traditional shopping zone (Sikos T. - Hoffmann-né 2004) created suitable conditions for art traders in the downtown. Secondly, the present location of the art trade center might have been influenced by the financial and economic role of district $\mathrm{V}$, as well as by the presence of state and government administration institutions. Those highprestige, wealthy members of the society who lived in the tenement houses in the nearby streets (including Falk Miksa utca) and held positions in state administration were also interested in collecting art pieces, thus contributing to creating the traditions of art trade in the downtown area. In Hungary during the socialist era the state-owned Bizományi Áruház Vállalat (BÁV - Consignment Shop) had a monopoly in pawning and art trading, and opened its first art trade shop in this downtown area. Some decades later, from the 1980s, art trading companies appeared after each other (Martos, 2012) in the neighborhood of BÁV, then, after the change of the regime, Falk Miksa utca received its present character. As the interviews revealed, this was a very slow process, because previously wealth-accummulating in art was mainly restricted to collecting furniture made for individual orders only, since the state regulated the purchase of art works. The first decisive and most characteristic player in the 
street was a picture framer who became later a trader in art. This was followed step by step by another private art shops in the street.

Figure 1 Spatial characteristics of art trade in Budapest (2017)

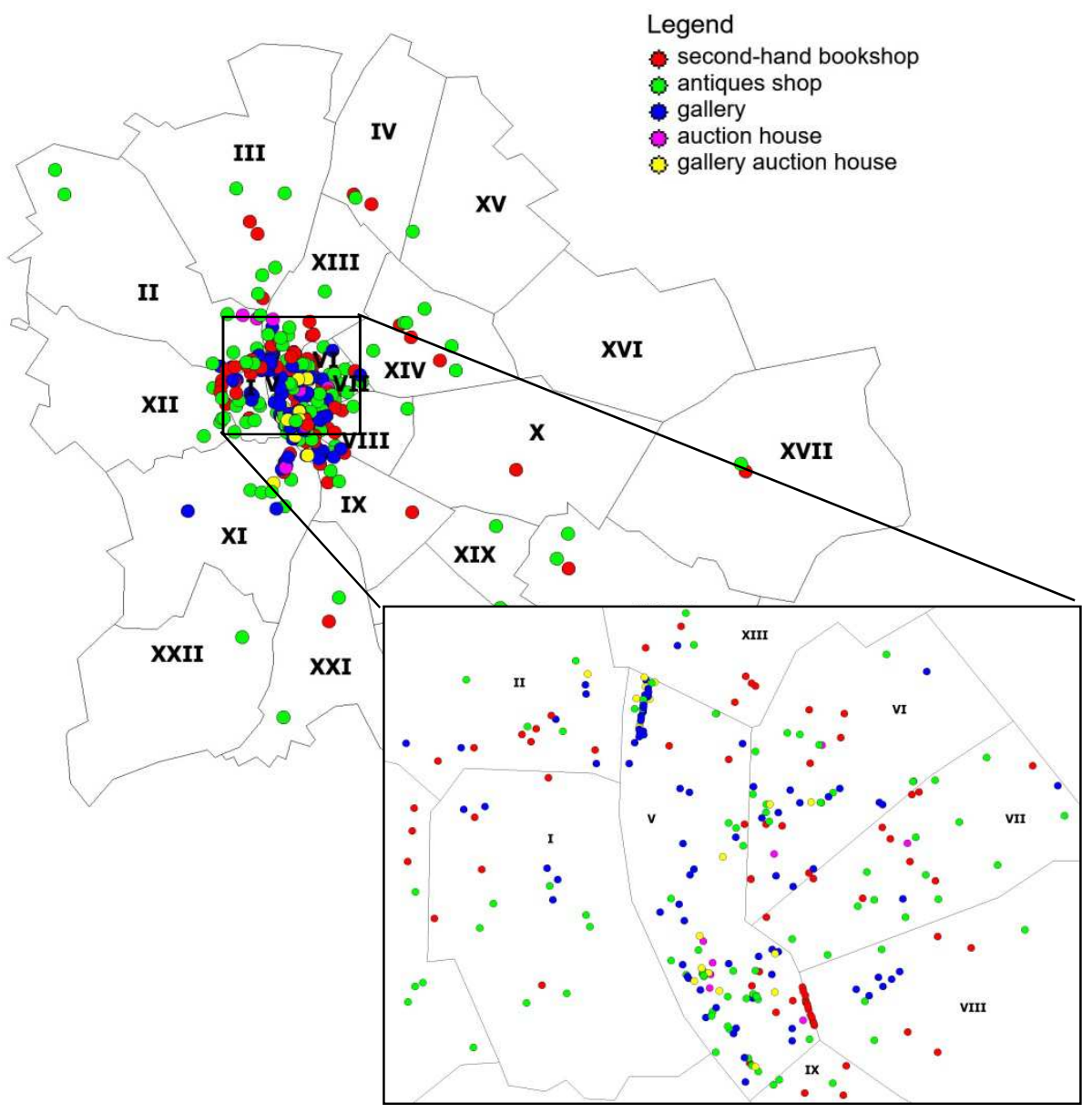

Source: own edition based on own data

\section{Spatial characteristics of art trade in the countryside}

When we examine the spatial distribution of art shops, we cannot rely exclusively on map representation tools, since identifying the reasons for regional differences which derive from the heterogeneity of space, social, economic and cultural factors must also be considered. Settlements of different sizes, with different histories and functions provided different conditions and possibilities for the appearance of art traders, so due to this fact, the different features of the settlement network also have to be examined. As Table 2 shows, in case of towns with more than 1,000 inhabitants, the PEX index of second-hand bookshops and antiques shops reaches the maximum, which means that in all of the seven settlements there is at least one shop of these kinds. This is not surprising because second-hand bookshops and antiques shops together account for more than $70 \%$ of art trade shops in the countryside. They are inevitably the most common types. The largest number of second-hand bookshops can be 
found in Debrecen (8), and another 4-6 are located in the city of Miskolc, Kecskemét and Szeged. In Szeged eight antiques shops operate altogether, followed by seven in Győr. In Debrecen, Kecskemét and Nyíregyháza only 1-2 antiques shops were registered in the examined period. In this settlement category the presence of commercial galleries can also be considered high, there is a for-profit gallery in all of them, except for Miskolc. Győr and Pécs are outstanding from this respect, where 6-8 shops deal with paintings. Except for Budapest, gallery auction houses can only be found in settlements with more than 100,000 inhabitants, in less than a half of the cities of this size operates this kind of shop. As Werck-HeyndelsGeys (2008) point out, cultural activities are only economically viable if the critical mass of consumers is also present there. Obviously, buying, selling and auctioning art works of great value is only profitable if there is a large number of potential customers with high disposable income, so because of this, auction houses can only survive for a long time in big city environment. Auctions were organized by one commercial house in Debrecen and one in Kecskemét, and by two of them in Pécs in the researched period. In settlements with inhabitants between 50-100,000 the competition is tight for the different types of art traders. In Zalaegerszeg five second-hand bookshops and three galleries bring some color to the local retail sector, while in Veszprém five galleries, four second-hand bookshops and three antiques shops define the local art market. In Szolnok and Sopron another two or three shops represent the different types. In the category of settlements with inhabitants between 25-50,000, which includes 25 cities, the dominance of second-hand bookshops and antiques shops can be observed. The PEX-value is higher for antiques shops (0.61) than for second-hand bookshops (0.57). Until now there are 17 settlements with some kind of art store, the number of settlements with an antiques shop is one higher than that of with a second-hand bookshop. In this category the presence of commercial galleries is smaller, only one-third of the towns have this type of art shop.

Table 2 Penetration (PEX) indices of art traders in the countrysie

\begin{tabular}{c|c|cc|cc|cc|cr}
\hline $\begin{array}{c}\text { Size of settlement } \\
\text { (1000 people) }\end{array}$ & $\begin{array}{c}\text { Number of } \\
\text { settlements }\end{array}$ & \multicolumn{2}{|c|}{$\begin{array}{c}\text { Second- } \\
\text { hand } \\
\text { bookshop }\end{array}$} & \multicolumn{2}{|c|}{$\begin{array}{c}\text { Antiques } \\
\text { shop }\end{array}$} & Art gallery & \multicolumn{2}{c}{$\begin{array}{c}\text { Auction } \\
\text { house }\end{array}$} \\
\cline { 2 - 13 } & & pcs. & PEX & pcs. & PEX & pcs. & PEX & pcs. PEX \\
\hline over 100 & 7 & 7 & 1,000 & 7 & 1,000 & 6 & 0,857 & 3 & 0,428 \\
\hline $50-100$ & 11 & 9 & 0,818 & 7 & 0,636 & 8 & 0,727 & 0 & 0,000 \\
\hline $50-25$ & 28 & 16 & 0,571 & 17 & 0,607 & 10 & 0,357 & 0 & 0,000 \\
\hline $25-10$ & 96 & 9 & 0,093 & 15 & 0,156 & 6 & 0,062 & 0 & 0,000 \\
\hline under10 & 3012 & 8 & 0,002 & 17 & 0,005 & 12 & 0,003 & 0 & 0,000 \\
\hline
\end{tabular}

Source: Own calculation based on Tiner (2010) 
Szentendre's city center is enriched by six for-profit galleries, and when talking about this settlement category, two art saloons in Siófok and two in Cegléd must also be mentioned. The number of antiques shops is outstandingly high in Vác (5), while in Esztergom and Baja three, and in Budaörs two shops deal with retailing antique art pieces. The retail outlet network of Szentes and Szentendre are enriched with three second-hand bookshops in each, in Cegléd and Gyöngyös two and two shops of this kind can be found. If we examine the map on Fig. 2, there are more differences in the regional dispersion of the different types. Although art traders are concentrated mainly in cities with larger population, a greater number of secondhand bookshops can be found in the university cities (Debrecen, Miskolc, Kecskemét and Szeged) in the eastern part of the country. Commercial galleries mainly operate in the Transdanubia. All these can be explained by the differences in regional development, in living standards and in income levels. While demand for used coursebooks and university notes among students in the eastern counties of Hungary is higher, this is less characteristic for the western part of the country. At the same time, profitable operation of commercial galleries requires customers with higher income level, so spatial distribution of galleries adjusts to demand. Spatial distribution of antiques shops shows a more even distribution, shops are less concentrated in large cities. This is verified by the fact that in settlements with a population of 10-25,000 inhabitants antiques shops are the most common type (Table 2), in 15 out of the 96 towns can this kind of retail unit be fount. Not only retailing in antiques is vivid in small- and medium sized towns, but as our data collection pointed out, among art traders in the countryside it is rather commmmon to buy up inherited items, and so is paying for the antique goods in cash. However, in this group of settlements the PEX index does not even reach 0.1. Although the number of art traders is very low in this settlement category, in Balatonfüred there are three, in Biatorbágy and Kisvárda two and two of them await prospective buyers, and in Balassagyarmat three second-hand bookshops operate at the same time. In Keszthely two commercial galleries and two antiques shops enrich the supply. We can state that in the category of settlements with fewer than 10,000 inhabitants, none of the types is significantly present. In general, there is one art trade shop in each settlement, only the two commercial galleries in the town of Tokaj and the two antiques shops in Balatonalmádi are exceptions. We also should examine the geographical location and the different settlement features of the municipalities and large villages in question. In many cases the gallery does not operate in the central settlement, but in the gravity zone is there an art saloon (Nagycenk-Sopron, Szabadbattyán-Székesfehérvár, Vértesszőlős-Tatabánya). These agglomeration forces work in the attraction zone of the capital, in the case of art traders in Budaörs, Biatorbány and Pilisvörösvár. In cities with larger population near Lake Balaton (Balatonfüred, Keszthely, 
Siófok), and in smaller settlements (Badacsonytomaj, Balatonakali, Balatonalmádi, Hévíz) the different kinds of shops and galleries are also present, which can be explained primarily by the demand-stimulating role of toursim. Similarly, touristic activities stimulate local art trading activities in the Tokaj wine region, and in towns rich in cultural heritage sites (Eger, Esztergom, Sopron, Veszprém). We must mention the antiques fair in the Danube bend, which is famous throughout the country. Its development can be led back to several facotrs. Besides the picturesque scenery and the numerous sights, the region has a favorable geographical location, the proximity of Budapest creates ideal market environment for antiques shops in Vác and Visegrád. At the same time in the Danube bend traditions of cultural and art life go back to centuries. Apart from the famous artists' colony in Szentendre, the free school of fine arts in Zebegény and other art workshops, which still operate today, all enhanced the appearance of galleries and art traders in the neighboring settlements (Nagymaros, Sződ, Verőce). In the 1990s another famous artists' colonies were established in Hungary whose spirit remained and is still carried on by second-hand booshops, antiques shops or a gallery (Gödöllő, Hódmezővásárhely, Kecskemét, Szolnok). The spatial distribution of art shops in a particular county also reflects local history. In settlements with rich historical past and civil traditions (Balassagyarmat, Tata) art shops appear in a greater number than in younger county administrative seats which are mostly industrial cities (Salgótarján, Tatabánya).

Figure 2 Spatial characteristics of art trade in the countryside (2017)

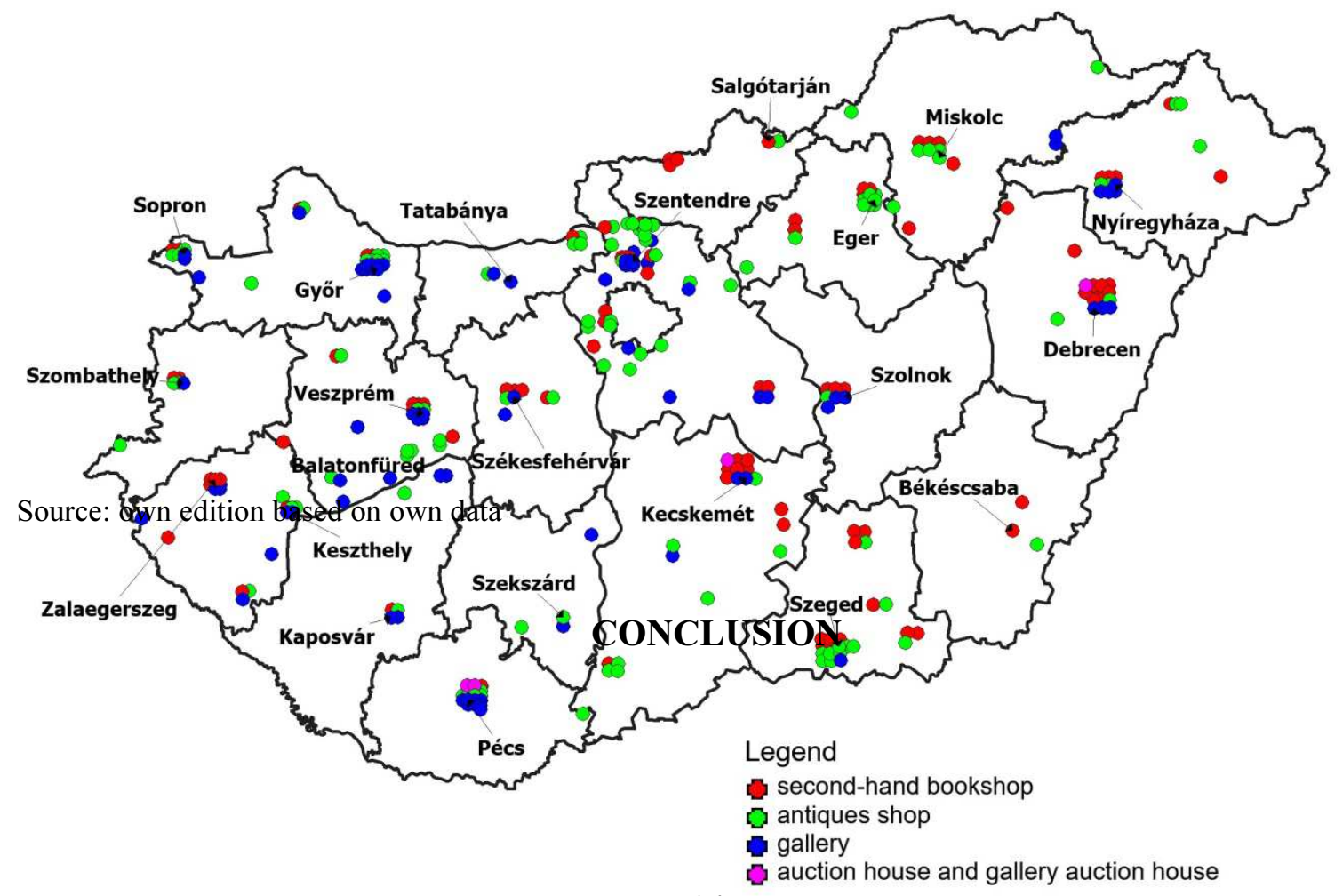


Although the center of art trade in Hungary is inevitably Budapest, art trading activites in the countryside are also remarkable. If we examine the spatial distribution of art traders by type, we can state that auction houses, gallery auction houses and commercial galleries are mainly centered in the captial, while the proportion of second-hand bookshops is higher in the countryside. At the influential trading houses of the art market multi-channel distribution can often be observed, some auctions in the countryside carry metropolitan features (auction in the offsite center of the company in Budapest or on an online market). Because of their art patronage activities and cultural functions, in most cases galleries create homepages, many of them apply a fixed price policy and sell locally. In the countryside antiques shops appear in greater proportion on the online distribution channels, which goes back to reasons for competitiveness. Compared to this, in Budapest second-hand bookshops do this, due to their advantages in distribution activities. Considering that creating an own web shop, operating it profitably, and developing it constantly requires remarkable expertise and financial investment, and this investment mostly yields profit for larger trading houses, besides auction houses mainly antiques shops in the capital do so. A more cost-effective way of appearing on online spaces is $\mathrm{C} 2 \mathrm{C}$ markets, using the services offered by art advertising portals, which is characteristic for antiques shops in the countryside. It is also a favorable opportunity for second-hand bookshops in Budapest to increase sales. The most elegant business district in Budapest mainly provides home for reputable auction houses and gallery auction houses, but the majority of the galleries are also located in the downtown area. Second-hand bookshops and antiques shops are mostly centered in the area around the city center and in the districts in Buda. Spatial separation of the different types of shops can be explained by the differences in rental fees. The development of traditional art trade and second-hand bookshop centers was greatly affected by tradition, the proximity of contemporary public institutions, and the presence of a trading house with a central role, while in Buda their appearance near the Buda Castle was induced by flourishing tourism.

If we examine the occurrence of the individual types according to the categories of settlement sizes, we see that auction houses in the countryside can be found in cities with a population over 100,000 people, where market conditions for profitable operation are provided. The occurrence of commercial galleries in settlements with fewer than 50,000 inhabitants is rather small, their spatial distribution matches demand. In settlements with inhabitants between 25 50,000 people, the presence of antiques shops and second-hand bookshops is still remarkable. The size category where the business environment is still favorable for their activity is about 10,000 inhabitants. Concentration of second-hand bookshops is considerable mainly in 
university cities, while the spatial distribution of antiques shops is more even. Tourism might have a demand-stimulating role in the settlements around Lake Balaton, and in cities and towns rich in historical sites and architectural heritage. In certain cases the individual types appear in the agglomeration zone instead of the central settlement. Traditions of art trade can be observed in towns with great civic history, but galleries can also keep alive the memories of old artists' colonies or vivid cultural life.

\section{REFERENCES}

Dekker, E. (2015). Two approaches to study the value of art and culture, and the emergence of a third. Journal of Cultural Economics, 39, 309-326

Enyedi, G. (2002). A városok kulturális gazdasága. [Cultural economy of cities] Földrajzi Ertesítö, 51 (1-2), 19-29

Enyedi, G. (2012). Városi világ. [City world] Budapest: Akadémiai Kiadó

Martos, G. (2012). Mükereskedelem. Egy cápa ára. [Art trade. Price of a shark] Budapest: Typotex Kiadó

Meyer, J-A., Even, R. (1998). Marketing and the Fine Arts - Inventory of a Controversial Relationship. Journal of Cultural Economics, 22, 271-283

Nemes Nagy J. (2009). Terek, helyek, régiók. [Spaces, places, regions] Budapest: Akadémiai Kiadó

Potts, J., Cunningham, S., Hartley, J., Ormerod, P. (2008). Social network markets: a new definition of the creative industries. Journal of Cultural Economics, 32, 167-185

Pratt, A. C.-Jeffcutt, P. (2009). Creativity, innovation and the cultural economy. Snake oil for the twenty-first century? In Pratt, A. C.-Jeffcutt, P. (Eds.), Creaivity, Innovation and the Cultural Economy (pp. 3-19). Routledge, Taylor \& Francis e-Library

Prinz, A., Piening, J., Ehrmann, T. (2015). The success of art galleries: a dynamic model with competition and information effects. Journal of Cultural Economics, 39, 153-176

Rechnitzer, J. (2002). (Mü)gyüjteni, de hogyan? [(Art)collection. How to do it?] Győr: Régió Art Kiadó

Sikos, T. T. (2000). Marketingföldrajz. [Marketing geography] VÁTI Kht. Komárom: Komáromi Nyomda és Kiadó Kft.

Sikos, T. T., Hoffmann I-né (2004). A fogyasztás új katedrálisai. [New cathedrals of consumption] MTA Társadalomkutató Központ. Budapest: Folpress Nyomdaipari Kft.

Tiner, T. (2010). Kereskedelmi nagylétesítmények telephelyválasztási kritériumai Magyarországon [Site-selection criteria of large retail units in Hungary] In Sikos T. (Ed.), Fenntartható fogyasztás és növekedés határai. Új trendek a kereskedelemben. (pp. 69-96). Gödöllö-Komárom: Selye János Egyetem Kutatóintézete.

Várnai I. (2017). A hazai mükereskedelem tipológiája és térbeli jellegzetességei Budapest példáján. [Typology and spatial characteristics of Hungarian art trade. The example of Budapest $]$ Tér és Társadalom, 31 (2), 104-119

Werck, K., Heyndels, B., Geys, B. (2008). The impact of 'central places' on spatial spending patterns: evidence from Flemish local government cultural expenditures. Journal of Cultural Economics, 32, 35-58 